\title{
Gender and Age Do Matter: Exploring the Effect of Passengers' Gender and Age on the Perception of Light Rail Transit Service Quality in Kuala Lumpur, Malaysia
}

\author{
Ahmad Nazrul Hakimi Ibrahim ${ }^{1} \mathbb{D}$, Muhamad Nazri Borhan ${ }^{1,2, *} \mathbb{D}$, Nur Izzi Md. Yusoff ${ }^{1,2}$, Amiruddin Ismail ${ }^{1}$, \\ Muhamad Razuhanafi Mat Yazid ${ }^{1,2}$, Nor Aznirahani Mhd Yunin ${ }^{3}$ and Sotaro Yukawa ${ }^{4}$ \\ 1 Department of Civil Engineering, Faculty of Engineering and Built Environment, Universiti Kebangsaan \\ Malaysia, Bangi 43600, Malaysia; nazrulhakimi@siswa.ukm.edu.my (A.N.H.I.); izzi@ukm.edu.my (N.I.M.Y.); \\ aismail@ukm.edu.my (A.I.); razuhanafi@ukm.edu.my (M.R.M.Y.) \\ 2 Sustainable Urban Transport Research Centre (SUTRA), Faculty of Engineering and Built Environment, \\ Universiti Kebangsaan Malaysia, Bangi 43600, Malaysia \\ 3 Road Traffic and Infrastructure Unit (RTI), Malaysian Institute of Road Safety Research (MIROS), \\ Taman Kajang Sentral, Kajang 43000, Malaysia; noraznirahani@miros.gov.my \\ 4 Department of Economics, Osaka University of Commerce, Mikuriyasakae-machi, Higashiosaka-shi, \\ Osaka 577-8505, Japan; s77yukawa@nifty.com \\ * Correspondence: mnazri_borhan@ukm.edu.my
}

Citation: Ibrahim, A.N.H.; Borhan, M.N.; Md. Yusoff, N.I.; Ismail, A.; Mat Yazid, M.R.; Mhd Yunin, N.A.; Yukawa, S. Gender and Age Do Matter: Exploring the Effect of Passengers' Gender and Age on the Perception of Light Rail Transit Service Quality in Kuala Lumpur, Malaysia. Sustainability 2021, 13, 990. https:// doi.org/10.3390/su13020990

Received: 4 December 2020

Accepted: 14 January 2021

Published: 19 January 2021

Publisher's Note: MDPI stays neutral with regard to jurisdictional claims in published maps and institutional affiliations.

Copyright: (c) 2021 by the authors. Licensee MDPI, Basel, Switzerland. This article is an open access article distributed under the terms and conditions of the Creative Commons Attribution (CC BY) license (https:// creativecommons.org/licenses/by/ $4.0 /)$.

\begin{abstract}
Light rail transit (LRT) is a sustainable transportation mode that ensures sustainable environmental, economic, and social development. Generally, the rate of public transportation usage in many parts of the world remains low compared to private vehicles. There is a need to understand passengers' perception of public transportation service quality to enhance passenger satisfaction and increase ridership. Thus, this study used the Kuala Lumpur LRT service as a case study to investigate the effect of a passenger's gender and age on their perception of the LRT service quality and their overall satisfaction. This survey involved 417 respondents. The outcome of factor analysis indicated that eight factors-i.e., signage, comfort, speediness, safety, ticketing service, facilities, staff service, and provision of information-influenced passenger satisfaction. The results of the Mann-Whitney U test and Kruskal-Wallis test indicated that the factors influencing passenger satisfaction significantly varied across a passenger's gender and age. A more in-depth and comprehensive analysis using the ordered logit model and segmentation approach proved that provision of information, comfort, staff service, and facilities were critical determiners of passenger satisfaction in most segments. Safety factors and ticketing services had no impact on overall passenger satisfaction. The findings of this research could help LRT service providers, researchers, and policymakers formulate effective strategies for enhancing passenger satisfaction and increase the ridership for LRT services.
\end{abstract}

Keywords: gender; light rail transit; public transportation; satisfaction; service quality; sociodemographic characteristic

\section{Introduction}

Many countries across the globe are experiencing rapid urbanization and population growth [1], both of which have significantly increased economic growth and global demand for mobility. The rate of motorization has increased rapidly with a high dependency on private transportation for mobility. In 2010, the use of public transport in Greater Kuala Lumpur was relatively low at 17\% (1.24 million) and 83\% (6 million) of the trips involved the use of private vehicles $[2,3]$. Statistics also showed that the use of public transportation in Malaysia is relatively low compared to the other cities in the world, including London (90\%), Hong Kong (74\%), and Singapore (64\%) [3,4]. The most common reasons for using private transportation are privacy, speed, and flexibility [5]. 
The public must be encouraged to reduce their dependency on private transportation and use public transportation. Numerous studies in the transportation field reported the positive effect of using public transportation, including reduced risk of road accidents, traffic congestion, pollution, and global warming [6-9]. Soehodho [10] has shown that improved public transportation development in Indonesia has increased ridership and reduced traffic accidents. According to Satiennam et al. [11] and Kwan et al. [12], the use of public transportation reduces global warming since this mode of transportation emits less carbon dioxide $\left(\mathrm{CO}_{2}\right)$ than private transportation. Other studies projected that expanding public transportation and active transportation in city areas will reduce $40 \%$ of the urban passenger transportation emissions by 2050 [8]. One of the ways of doing this is by increasing the ridership for public transportation, as this is one of the key strategies for achieving sustainability. According to Ibrahim et al. [4], sustainable transportation is a transportation system that has environmental, economic, and social benefits. Public transport is the critical factor in the global effort to achieve sustainable transportation, and light rail transit (LRT) is a sustainable transportation mode that contribute towards sustainable environmental, economic, and social development.

One of the ways to achieve sustainable mobility and transportation development in urban areas is by encouraging LRT usage. Even though the public is aware of the significance of sustainable transportation, most of them still exhibit limited structural behavior aimed at transportation sustainability $[13,14]$, which is evident by the lower public acceptance of public transportation as a commuting alternative [15-18]. Despite the fact the government and authorities strongly encourage the use of public transport, the response from the public is still disappointing. According to Masirin et al. [19], the rate of railway ridership in the Klang Valley is still low even though the government has invested a large amount of money promoting the use of railway services since the past few years. Several studies on the rail-based public transportation in Malaysia reported a low ridership for this mode of public transportation [15-17]. According to Van Lierop et al. [18], many rail-based transport services throughout the world have to deal with the same problem.

Several studies [20-24] proposed increasing the ridership of rail-based transportation by enhancing passenger satisfaction through high-quality service. According to Zafreh et al. [7], passengers' satisfaction can contribute to retaining existing passengers and attracting new passengers. In public transportation, passenger satisfaction is the extent the expectations or needs of passengers are fulfilled by the provided service [25]. Many previous studies in the transportation literature discussed the effect of passenger satisfaction on public transportation service. For instance, Irtema et al. [26] reported that the service quality of public transportation in Kuala Lumpur, Malaysia is a critical determiner of satisfaction and behavioral intention. In a case study of the High-Speed Rail in Turkey, Yilmaz, and Ari [27] proved that service quality influenced passenger satisfaction, reduced complaint behavior, and increased passenger loyalty. Other studies [28,29] that investigated the relationship between service quality, passenger satisfaction, passenger complaints, and loyalty reported similar findings. A study in Hong Kong discovered that satisfaction has a direct and significant impact on the intention to use the Mass Rapid Transit service [30]. Service quality is a critical determiner of passenger satisfaction with public transportation [26-30]. According to de Ona et al. [31], there is no consensus concerning the factors of public transportation service quality that should be considered in the investigation of the perception of service quality. The attributes vary depending on the authors, location of the study, and type of public transportation, as shown in Table 1.

The studies listed in Table 1 used the stated preference surveys to evaluate passenger's perception of public transportation service quality. This approach has been criticized for lack of realism because it does not realistically represent the actual choice situation $[32,33]$. According to the previous literature, one of the suggested methods for improving realism is perception recognition via the visual attribute (images) approach such as eye-tracking devices [34-36] and virtual reality [37-39]. The use of eye-tracking devices and virtual reality is still limited in the transportation field, and the findings related to these approaches 
are rarely reported in the scientific journal [39]. One of the studies using these approaches in the transportation literature was by Sobhani et al. [40], which employed virtual reality to evaluate pedestrian's distracted behavior while crossing the road. The study found that distracted pedestrians usually wait longer but cross the street quicker compared to nondistracted participants. Simpson et al. [41] investigated the crossing behavior of children and young adults and found that the decision to cross the street was based on the distance between cars and not speed. The most recent study reported that virtual reality could identify the factors that influence cycling as a commuting mode [39]. Thus, this approach is suitable for investigating the perception of public transportation service quality since it can improve accuracy and reliability.

In addition, previous studies [31,42] on human behavior have shown that passenger satisfaction is critical to dealing with a high degree of heterogeneity. Various studies in the transportation literature analyzed the heterogeneity of passenger's perception through segmentation based on socio-demographic characteristics such as gender, age, occupation status, education background, income, and others [31,43-47], frequency of using public transportation [44,45], travel pattern [48], and passenger's attitudes toward public transportation $[49,50]$.

The segmentation approach gives more specific and accurate information on the satisfaction of a specific passenger segment with public transportation. It also provides useful information that can help authorities, policymakers, planners, and researchers to formulate effective strategies that target a specific population, such as male and female passengers, young and old passengers, and others. However, very few researchers have adopted the segmentation approach to understand passenger's perception of public transportation in Asian countries, especially Malaysia. For this reason, public transportation service providers should do a better analysis of passenger characteristics and should not neglect the effects of demographic factors. This research will attempt to bridge this gap by taking the Kuala Lumpur light rail transit (LRT) system as a case study to investigate how passenger gender and age influence the perception of the LRT service.

Section 2 discusses the methodology adopted in this study. Section 3 presents the findings of this research, and Section 4 discusses the results and elucidates theoretical and practical implications. Section 5 presents the conclusions of this research and suggestions for future research. 
Table 1. Quality of service attributes for public transportation.

\begin{tabular}{|c|c|c|c|c|c|c|c|c|c|c|c|c|c|c|c|}
\hline & Country & NL & MY & IT & KE & MY & ES & ES & CS & EU & NG & $\mathrm{CN}$ & IT & DZ & TR \\
\hline & Mode of Public Transportation & 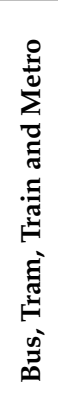 & 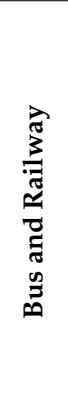 & $\frac{\vec{\pi}}{\stackrel{3}{3}}$ & 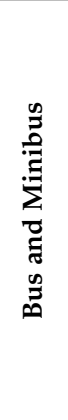 & 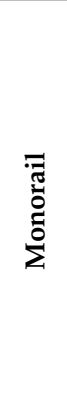 & $\stackrel{n}{己}$ & $\stackrel{\mathscr{D}}{\partial}$ & $\stackrel{\infty}{ٍ}$ & 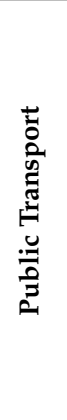 & $\stackrel{\infty}{\not}$ & $\frac{\vec{\pi}}{3}$ & 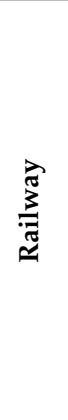 & 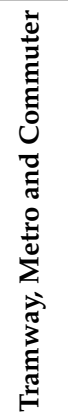 & 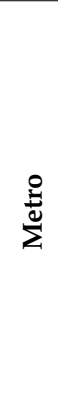 \\
\hline \multirow{27}{*}{ 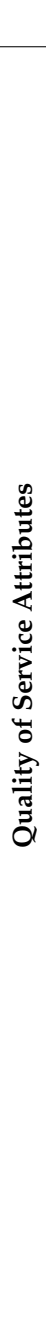 } & References & [8] & [26] & [44] & [51] & [52] & [53] & [54] & [55] & [56] & [57] & [58] & [59] & {$[60]$} & [61] \\
\hline & Frequency & $\bullet$ & $\bullet$ & $\bullet$ & $\bullet$ & & $\bullet$ & $\bullet$ & & $\bullet$ & $\bullet$ & $\bullet$ & $\bullet$ & $\bullet$ & \\
\hline & Network coverage & & & & & $\bullet$ & & & $\bullet$ & $\bullet$ & & & $\bullet$ & $\bullet$ & \\
\hline & Service provision hours & & $\bullet$ & & & & & & & & & $\bullet$ & • & $\bullet$ & \\
\hline & Station parking & & & $\bullet$ & & $\bullet$ & & $\bullet$ & & & & & & & \\
\hline & Accessibility & $\bullet$ & & & & $\bullet$ & $\bullet$ & & & & $\bullet$ & & $\bullet$ & $\bullet$ & $\bullet$ \\
\hline & Easy of transfer/Distance & & & & & & & & & $\bullet$ & & & $\bullet$ & $\bullet$ & \\
\hline & Ticket price & $\bullet$ & $\bullet$ & $\bullet$ & $\bullet$ & $\bullet$ & $\bullet$ & $\bullet$ & $\bullet$ & & & $\bullet$ & $\bullet$ & $\bullet$ & \\
\hline & Ticket selling network & $\bullet$ & $\bullet$ & & & $\bullet$ & & & & & & $\bullet$ & $\bullet$ & $\bullet$ & \\
\hline & Type of tickets/Passes & & & & $\bullet$ & & & & & & & $\bullet$ & $\bullet$ & & \\
\hline & On board information & $\bullet$ & $\bullet$ & $\bullet$ & & $\bullet$ & $\bullet$ & $\bullet$ & & & & $\bullet$ & $\bullet$ & $\bullet$ & \\
\hline & Information at station & $\bullet$ & $\bullet$ & $\bullet$ & & & & $\bullet$ & & & & $\bullet$ & $\bullet$ & $\bullet$ & \\
\hline & Punctuality & $\bullet$ & & $\bullet$ & $\bullet$ & $\bullet$ & $\bullet$ & $\bullet$ & $\bullet$ & & & $\bullet$ & $\bullet$ & $\bullet$ & $\bullet$ \\
\hline & Access time & $\bullet$ & & & & & $\bullet$ & & & $\bullet$ & $\bullet$ & $\bullet$ & $\bullet$ & $\bullet$ & \\
\hline & Travel speed & $\bullet$ & & & & & $\bullet$ & & & & & $\bullet$ & $\bullet$ & $\bullet$ & $\bullet$ \\
\hline & Waiting time & & & & & & & & • & & $\bullet$ & & & $\bullet$ & $\bullet$ \\
\hline & Driver and personnel's behavior & $\bullet$ & $\bullet$ & $\bullet$ & & $\bullet$ & $\bullet$ & $\bullet$ & $\bullet$ & & & $\bullet$ & $\bullet$ & 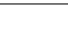 & $\bullet$ \\
\hline & Customer service & & $\bullet$ & & $\bullet$ & & & & & & & & & $\bullet$ & \\
\hline & Cleanliness & $\bullet$ & & $\bullet$ & & $\bullet$ & $\bullet$ & $\bullet$ & $\bullet$ & & $\bullet$ & $\bullet$ & • & $\bullet$ & $\bullet$ \\
\hline & Comfort & $\bullet$ & & $\bullet$ & $\bullet$ & $\bullet$ & • & $\bullet$ & & $\bullet$ & $\bullet$ & $\bullet$ & $\bullet$ & $\bullet$ & $\bullet$ \\
\hline & Seating capacity & $\bullet$ & & & & $\bullet$ & & & & $\bullet$ & $\bullet$ & $\bullet$ & $\bullet$ & $\bullet$ & $\bullet$ \\
\hline & Quality of vehicles & & & $\bullet$ & & & & $\bullet$ & & & $\bullet$ & & $\bullet$ & $\bullet$ & \\
\hline & Temperature & & & & & & $\bullet$ & & $\bullet$ & & & $\bullet$ & & $\bullet$ & $\bullet$ \\
\hline & Waiting condition & & & & $\bullet$ & $\bullet$ & & & & $\bullet$ & $\bullet$ & & & & \\
\hline & On board safety & $\bullet$ & $\bullet$ & $\bullet$ & $\bullet$ & $\bullet$ & $\bullet$ & $\bullet$ & & & & $\bullet$ & $\bullet$ & $\bullet$ & $\bullet$ \\
\hline & Safety at station & $\bullet$ & $\bullet$ & & & & & & & $\bullet$ & & $\bullet$ & $\bullet$ & $\bullet$ & $\bullet$ \\
\hline & Total & 15 & 10 & 11 & 8 & 13 & 12 & 11 & 7 & 8 & 9 & 17 & 20 & 21 & 11 \\
\hline
\end{tabular}

Note: • represents that the article contains this type of dimension; NL: The Netherlands; MY: Malaysia; IT: Italy; KE: Kenya; ES: Spain; CS: Serbia; EU: Europe Countries; NG: Nigeria; CN: China; DZ: Algeria; TR: Turkey.

\section{Research Methodology}

\subsection{Case Study}

This case study aimed to explore the effect of gender and age on the perception of urban rail transit service quality. The Kuala Lumpur light rail transit (LRT) system operates in Klang Valley, Malaysia, which covers an area of $2793 \mathrm{~km}^{2}$ [12] and, in 2018, had a population of 7.564 million [62]. By the year 2020, Klang Valley is expected to have a population of 10 million [3,12]. The Kuala Lumpur LRT system consists of the Ampang Line and Kelana Jaya Line, as shown in Figure 1. Ampang Line, previously known as 
the Sistem Transit Aliran Ringan Sdn Bhd (STAR) Line, began operation in 1998. The Ampang Line is driver-operated and comprises two sub-lines, which run between the suburb of Sentul in the north of Kuala Lumpur and Ampang in the east, and Sri Petaling in the South [19]. The track branches off to either Ampang or Sri Petaling at the Chan Sow Lin Station about midway of both lines. The Ampang Line (Yellow Line in Figure 1) is $18 \mathrm{~km}$ long and has 18 stations, and the Sri Petaling Line (Light green Line in Figure 1) is $45.1 \mathrm{~km}$ long and has 29 stations. The Ampang Line has elevated at-grade stations and operates with 30 units of six-car trains with a capacity of 1000 passengers per train. The train frequency is 3 to $5 \mathrm{~min}$ during peak hours and 6 to $10 \mathrm{~min}$ during off-peak hours.

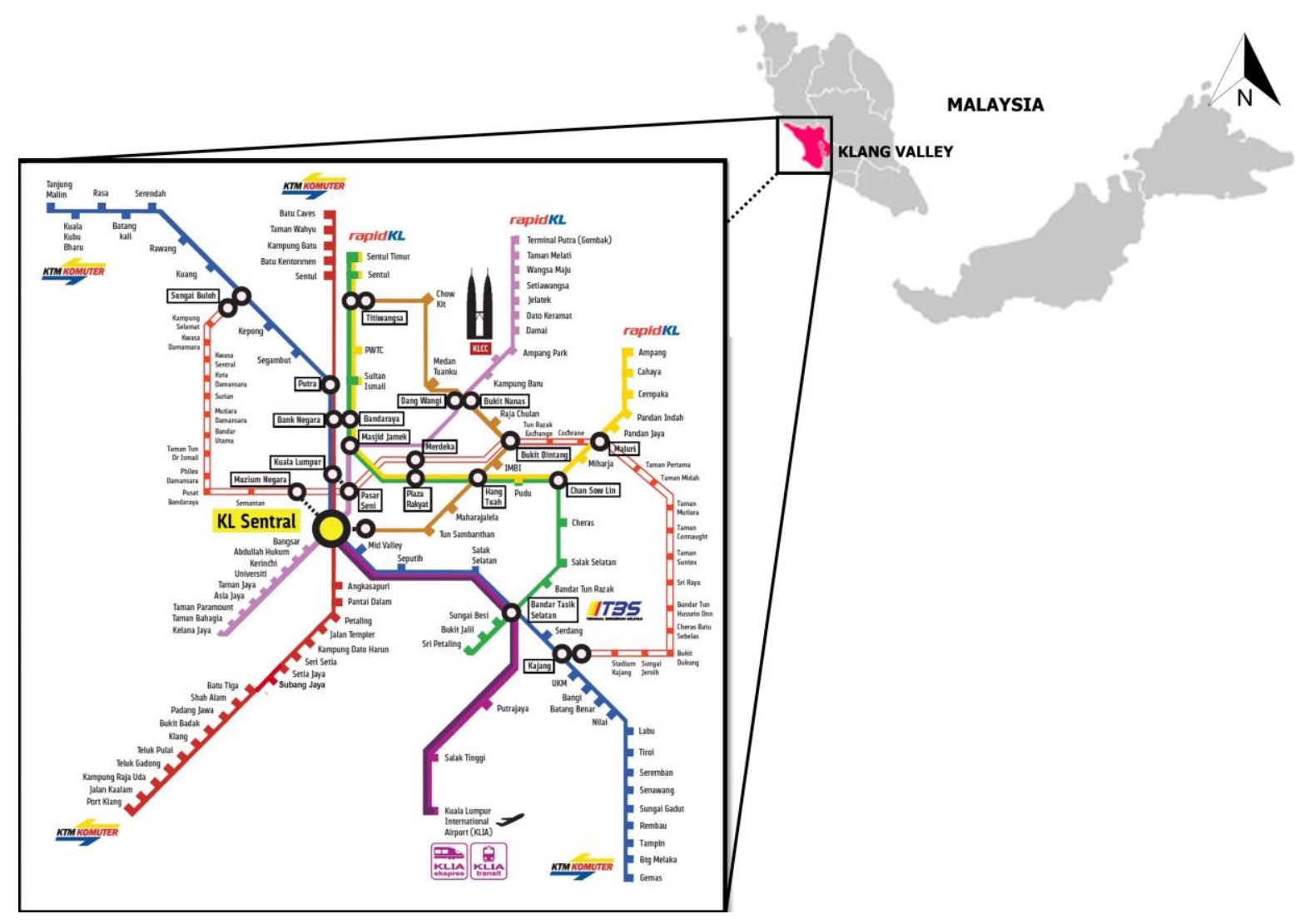

Figure 1. Kuala Lumpur rail transit network showing the Ampang line (yellow), Sri Petaling line (light green), and Kelana Jaya line (pink).

The Kelana Jaya Line, previously known as Projek Usahasama Transit Ringan Automatik Sdn Bhd (PUTRA) Line, began full operation in 1999. The Kelana Jaya Line is a fully-automated and driverless system and a single line connecting Petaling Jaya in the west to Gombak in the northeast (Pink Line in Figure 1). The Kelana Jaya Line is $46.4 \mathrm{~km}$ long and has 37 stations, where 31 stations are elevated, five are underground, and one (Sri Rampai Station) is an at-grade station. The Kelana Jaya Line operates with 35 units of two-car trains and 35 units of 4-car trains which can carry 740 passengers per train. The train frequency is $3 \mathrm{~min}$ during peak hours and 4 to 14 min during off-peak hours. The types of tickets/passes for the Ampang Line and Kelana Jaya Line are token (cash), Touch 'N Go (cashless), weekly pass (MyRapid TnG SMART7), and monthly pass (MyRapid TnG SMART30). 


\subsection{Design of the Survey}

The questionnaire in the present study was adapted from other similar studies in the field of public transportation, and the items from these studies were modified to suit the cultural, economic, and social context of Malaysia. The questionnaire was comprised of two sections. The first section consisted of seven items and gathered the demographic data of the respondents. The demographic measures were gender, age, education background, employment status, monthly income, driving license ownership, and car ownership. All items in this section were evaluated using a categorical scale. The second section was adapted from Kuo and Tang [23], Shen et al. [58], and Irtema et al. [26], examining 43 LRT quality of service and overall passenger satisfaction with the provided service (Appendix A). These items were measured using a five-point Likert scale, from $1=$ strongly dissatisfied to $5=$ strongly satisfied. A higher score indicates a higher interest in a specific measure. A pilot test was carried out by administering the questionnaire on 50 randomly selected respondents in Bandar Baru Bangi, Selangor to identify the weaknesses (errors or mistakes) in the designed instrument. The items in the questionnaire were then modified and rephrased to enhance their clarity and consistency $[63,64]$. Table 2 shows the outcomes of the reliability analysis of the pilot test.

Table 2. Construct items and reliability analysis of the instruments.

\begin{tabular}{ccc}
\hline Construct & Number of Items & Cronbach Alpha $(\boldsymbol{\alpha})$ \\
\hline 1. Signage & 5 & 0.841 \\
2. Comfort & 5 & 0.901 \\
3. Speediness & 4 & 0.896 \\
4. Safety & 8 & 0.813 \\
5. Ticketing service & 6 & 0.809 \\
6. Facilities & 7 & 0.801 \\
7. Staff service & 4 & 0.931 \\
8. Provision of information & 4 & 0.830 \\
\hline
\end{tabular}

\subsection{Sample Size and Data Collection}

The full-scale study was conducted in the Klang Valley, where the LRT operates. The data was gathered at stations with the highest passenger traffic, including Kuala Lumpur Sentral. The cross-sectional questionnaires were administered using a convenience sampling technique. The respondents in this study had to fulfill the two criteria: (i) they are a Malaysian citizen and (ii) have used the LRT service in the past month. Following that, the enumerators were briefed on the purpose of the survey and the potential respondents were asked if they were willing to participate in the survey. The questionnaire was given to those who were willing to participate to ensure an accurate and reliable response to each item in the questionnaire. Borhan et al. [9] believed that this approach could increase the response rate. The respondents were interviewed face-to-face and given a small token of appreciation at the end of the 10-15-min survey. Five hundred self-administrated questionnaires were administered between 20 September 2019 and 10 December 2019. In total, 83 of the returned questionnaires were eliminated due to invalid or/and incomplete response, and 417 were analyzed, giving an effective response rate of $83.40 \%$. Table 3 presents a summary of the respondent profile.

Table 3. Profile of the respondents $(n=417)$.

\begin{tabular}{cccc}
\hline Variable & Classification & Frequency (n) & Percentage (\%) \\
\hline \multirow{2}{*}{ Gender } & Male & 212 & 50.8 \\
& Female & 205 & 49.2 \\
\hline
\end{tabular}


Table 3. Cont.

\begin{tabular}{|c|c|c|c|}
\hline Variable & Classification & Frequency (n) & Percentage $(\%)$ \\
\hline \multirow{5}{*}{ Age (Years) } & Less than 20 & 38 & 9.1 \\
\hline & $21-30$ & 182 & 43.6 \\
\hline & $31-40$ & 156 & 37.4 \\
\hline & $41-50$ & 36 & 8.6 \\
\hline & Above 50 & 5 & 1.2 \\
\hline \multirow{5}{*}{ Education Background } & Primary School & 5 & 1.2 \\
\hline & Secondary School & 30 & 7.2 \\
\hline & College & 68 & 16.3 \\
\hline & University Degree & 311 & 74.6 \\
\hline & Others & 3 & 0.7 \\
\hline \multirow{5}{*}{ Employment Status } & Full-Time Employee & 233 & 55.9 \\
\hline & $\begin{array}{l}\text { Part-Time } \\
\text { Employee }\end{array}$ & 23 & 5.5 \\
\hline & Unemployed & 24 & 5.8 \\
\hline & Student & 135 & 32.4 \\
\hline & Others & 2 & 0.5 \\
\hline \multirow{6}{*}{$\begin{array}{l}\text { Income Range }(\text { MYR */Month) } \\
\quad \text { * Note: MYR } 1 \approx \text { USD } 0.23\end{array}$} & Less than 2000 & 122 & 29.3 \\
\hline & 2001-4000 & 72 & 17.3 \\
\hline & $4001-6000$ & 121 & 29 \\
\hline & 6001-8000 & 20 & 4.8 \\
\hline & More than 8000 & 4 & 1 \\
\hline & Confidential & 78 & 18.7 \\
\hline \multirow{2}{*}{ Driving License Ownership } & Yes & 356 & 85.4 \\
\hline & No & 61 & 14.6 \\
\hline \multirow{4}{*}{ Car Ownership } & 0 & 116 & 27.8 \\
\hline & 1 & 140 & 33.6 \\
\hline & 2 & 97 & 23.3 \\
\hline & More than 3 & 64 & 15.3 \\
\hline
\end{tabular}

\subsection{Data Analysis and Tools}

This study used IBM SPSS Statistics version 24.0 to analyze the data. The systematic procedure for analyzing the data includes an analysis of the respondents' demographic characteristics and exploratory factor analysis. The study also performed the MannWhitney $U$ test and Kruskal-Wallis test to determine the difference in passenger satisfaction with LRT service quality between independent groups (gender and age). Finally, the ordered logit model was used to investigate the effect of the association between gender and age on quality of service.

\section{Results}

\subsection{Exploratory Factor Analysis}

The exploratory factor analysis (EFA) identified the potential structure of the latent variables, which was then used to reduce the variables into a smaller and manageable size by removing the items that did not have common cores. This study selected the principal component (PC) technique for EFA since this technique is a highly recommended and widely used method in many applications to identify latent variables in transportation research $[23,43,45]$. This study retained the factors with eigenvalues greater than 1 [65-67].

Exploratory factor analysis was applied to the 43 items to measure the level of service quality of the Kuala Lumpur LRT. The results showed that eight factors, namely signage (5 items), comfort (5 items), speediness (4 items), safety (5 items), ticketing service (4 items), facilities (6 items), staff service (4 items), and provision of information (4 items), had eigenvalues greater than 1 and explained the $72.152 \%$ of the total variance. Following the recommendation by Maskey et al. [65] and Uca et al. [68], six items with a factor loading of less than 0.5 and were included in several factors were eliminated. The varimax rotation 
method was used in EFA to identify the critical factors and facilitate interpretation [69]. Three criteria are considered in the EFA: (i) the Kaiser-Meyer-Olkin (KMO) measure of sampling adequacy and Bartlett's test of sphericity, (ii) factor loading of the items, and (iii) reliability analysis of each identified factor. Table 4 shows that the KMO value (0.964) and Bartlett's test of sphericity $\left(\chi^{2}=16084.216, p<0.000\right)$ are significant, which indicate that the inter-correlation matrix has an adequate common variance and that there is high sampling adequacy for the factor analysis [69]. Table 4 shows that the factor loading for all samples ranges between 0.506 and 0.836 . Since factor loading greater than 0.50 indicates a satisfactory factor loading [23], all items were retained. Finally, the result of reliability analysis recommends a threshold value for Cronbach's alpha greater than 0.70. The Cronbach's alpha for all factors range between 0.897 and 0.947 (Table 4) and fulfils the requirement suggested by Hair et al. [69]. These values indicate that the eight extracted factors are highly reliable.

Table 4. Result of the exploratory factor analysis of the light rail transit (LRT) service quality.

\begin{tabular}{|c|c|c|c|c|}
\hline \multirow{2}{*}{ Factor/Item } & \multicolumn{4}{|c|}{ EFA } \\
\hline & Factor Loading & Eigenvalue & Explained Variance & Cronbach's Alpha \\
\hline Signage (SG) & & 14.839 & 34.509 & 0.903 \\
\hline SG1 & 0.651 & & & \\
\hline SG2 & 0.677 & & & \\
\hline SG3 & 0.698 & & & \\
\hline SG4 & 0.679 & & & \\
\hline SG5 & 0.639 & & & \\
\hline Comfort (CF) & & 7.419 & 17.254 & 0.912 \\
\hline CF1 & 0.599 & & & \\
\hline CF2 & 0.654 & & & \\
\hline CF3 & 0.661 & & & \\
\hline CF4 & 0.692 & & & \\
\hline CF5 & 0.625 & & & \\
\hline Facilities (FT) & & 2.212 & 5.145 & 0.947 \\
\hline FT1 & 0.753 & & & \\
\hline FT2 & 0.795 & & & \\
\hline FT3 & 0.808 & & & \\
\hline FT4 & 0.736 & & & \\
\hline FT5 & 0.702 & & & \\
\hline FT6 & 0.667 & & & \\
\hline Speediness (SN) & & 1.707 & 3.910 & 0.904 \\
\hline SN1 & 0.639 & & & \\
\hline SN2 & 0.703 & & & \\
\hline SN3 & 0.712 & & & \\
\hline SN4 & 0.679 & & & \\
\hline $\begin{array}{l}\text { Ticketing service } \\
\text { (TS) }\end{array}$ & & 1.471 & 3.421 & 0.908 \\
\hline TS1 & 0.630 & & & \\
\hline TS2 & 0.672 & & & \\
\hline TS3 & 0.611 & & & \\
\hline TS4 & 0.667 & & & \\
\hline Staff service (SS) & & 1.231 & 2.877 & 0.897 \\
\hline SS1 & 0.746 & & & \\
\hline SS2 & 0.759 & & & \\
\hline SS3 & 0.784 & & & \\
\hline SS4 & 0.738 & & & \\
\hline
\end{tabular}


Table 4. Cont.

\begin{tabular}{|c|c|c|c|c|}
\hline \multirow{2}{*}{ Factor/Item } & \multicolumn{4}{|c|}{ EFA } \\
\hline & Factor Loading & Eigenvalue & Explained Variance & Cronbach's Alpha \\
\hline Safety (ST) & & 1.148 & 2.670 & 0.912 \\
\hline ST1 & 0.506 & & & \\
\hline ST2 & 0.766 & & & \\
\hline ST3 & 0.753 & & & \\
\hline ST4 & 0.836 & & & \\
\hline ST5 & 0.514 & & & \\
\hline $\begin{array}{c}\text { Provision of } \\
\text { Information (PI) }\end{array}$ & & 1.017 & 2.366 & 0.929 \\
\hline PI1 & 0.552 & & & \\
\hline PI2 & 0.543 & & & \\
\hline PI3 & 0.531 & & & \\
\hline \multirow[t]{3}{*}{ PI4 } & 0.515 & & & \\
\hline & \multicolumn{4}{|c|}{$\mathrm{KMO}=0.964, \chi^{2}=16084.216, \mathrm{p}<0.000$} \\
\hline & \multicolumn{4}{|c|}{ Total variance explained $=72.152$} \\
\hline
\end{tabular}

Note: EFA = Exploratory factor analysis, $\mathrm{KMO}=$ Kaiser-Meyer-Olkin measure, $\chi^{2}=$ Bartlett's test of sphericity.

\subsection{Segment Analysis for Gender and Age}

A comparison of the effect of the eight factors quality of service on passenger's gender and age was made using the Mann-Whitney U test and Kruskal-Wallis test, respectively. The median of the factors of service quality ranges from 16 to 24 (Table 5). Three factors, speediness, staff service, and provision of information, have the lowest median $(\mathrm{M}=16)$ while facilities have the highest median $(M=24)$. However, Table 4 shows that there is a significant difference $(\mathrm{p}<0.05)$ between male $(\mathrm{n}=212)$ and female $(\mathrm{n}=205)$ passengers for signage, comfort, speediness, ticketing service, facilities, and provision of information. The Kruskal-Wallis test showed a significant variation $(\mathrm{p}<0.05)$ in five factors, namely signage, comfort, speediness, facilities, and provision of information.

Table 5. Effect of gender and age on passenger satisfaction with service quality.

\begin{tabular}{|c|c|c|c|c|c|}
\hline \multirow{2}{*}{ Quality of Service } & \multirow{2}{*}{$\mathbf{M}$} & \multicolumn{2}{|c|}{ Gender } & \multicolumn{2}{|c|}{ Age } \\
\hline & & $\mathrm{Z}^{\mathrm{a}}$ & p-Value (Asymp. Sig.) & Chi-Square $\left(\chi^{2}\right)^{b}$ & $p$-Value (Asymp. Sig.) \\
\hline 1. Signage & 20.000 & -3.632 & 0.000 & 17.834 & 0.001 \\
\hline 2. Comfort & 20.000 & -3.350 & 0.001 & 14.553 & 0.006 \\
\hline 3. Speediness & 16.000 & -2.957 & 0.003 & 17.795 & 0.001 \\
\hline 4. Safety & 20.000 & -0.240 & 0.811 & 1.596 & 0.810 \\
\hline 5. Ticketing service & 23.000 & -2.573 & 0.010 & 9.329 & 0.053 \\
\hline 6. Facilities & 24.000 & -5.313 & 0.000 & 37.315 & 0.000 \\
\hline 7. Staff service & 16.000 & -1.630 & 0.103 & 5.406 & 0.248 \\
\hline 8. Provision of Information & 16.000 & -4.665 & 0.000 & 21.837 & 0.000 \\
\hline
\end{tabular}

Note: ${ }^{\mathrm{a}}=\mathrm{Z}$ score for Mann-Whitney U test, ${ }^{\mathrm{b}}=$ Chi-square score for Kruskal-Wallis Tests, $\mathrm{M}=$ Median.

\subsection{Result of the Ordered Logit Model}

The last phase of this study investigated the key factors influencing the satisfaction of the different segments of LRT users. Several ordered logit models were developed and specified to determine the overall satisfaction, where the dependent variable is the Kuala Lumpur LRT service and the independent variables are the eight factors of service quality identified from the factor reduction process. Table 6 presents the five developed models, where Model 1 is a general model for the entire sample. Two models were developed for each of the variables: Model 2 for male respondents, Model 3 for female respondents, Model 4 for respondents less than 30 years old (18-30 years old), and Model 5 is for respondents over 30 years old. All models in this study did not consider gender and age since the two factors were used only for the segmented purpose. Age and gender were selected for the segmented purpose to avoid data heterogeneity and to conduct a more indepth analysis to identify the relevant aspects for specific segments (male, female, less than 
30 years old, and over 30 years old) as recommended by previous research [31,42]. Besides, the findings of this research can serve as a basis for developing specific improvement strategies targeting specific segment [47].

Table 6. Summary of the results for the ordered logit model.

\begin{tabular}{|c|c|c|c|c|c|c|c|c|c|c|}
\hline & \multicolumn{2}{|c|}{ Model 1} & \multicolumn{2}{|c|}{ Model 2} & \multicolumn{2}{|c|}{ Model 3} & \multicolumn{2}{|c|}{ Model 4} & \multicolumn{2}{|c|}{ Model 5} \\
\hline & \multicolumn{2}{|c|}{ General Model } & \multicolumn{2}{|c|}{ Male } & \multicolumn{2}{|c|}{ Female } & \multicolumn{2}{|c|}{ 18-30 Years Old } & \multicolumn{2}{|c|}{$\geq 31$ Years Old } \\
\hline & $\beta$ & S.E. & $\beta$ & S.E. & $\beta$ & S.E. & $\beta$ & S.E. & $\beta$ & S.E. \\
\hline 1. Signage & ns. & ns. & ns. & ns. & ns. & ns. & 0.096 & 0.058 & ns. & ns. \\
\hline 2. Comfort & 0.164 & 0.046 & ns. & ns. & 0.250 & 0.069 & 0.132 & 0.059 & 0.218 & 0.079 \\
\hline 3. Speediness & ns. & ns. & 0.156 & 0.077 & ns. & ns. & ns. & ns. & ns. & ns. \\
\hline 4. Safety & ns. & ns. & ns. & ns. & ns. & ns. & ns. & ns. & ns. & ns. \\
\hline 5. Ticketing service & ns. & ns. & ns. & ns. & ns. & ns. & ns. & ns. & ns. & ns. \\
\hline 6. Facilities & 0.071 & 0.031 & 0.070 & 0.041 & 0.114 & 0.051 & ns. & ns. & ns. & ns. \\
\hline 7. Staff service & 0.180 & 0.048 & 0.228 & 0.071 & ns. & ns. & 0.180 & 0.068 & 0.160 & 0.073 \\
\hline $\begin{array}{l}\text { 8. Provision of } \\
\text { information }\end{array}$ & 0.159 & 0.054 & 0.132 & 0.078 & 0.228 & 0.081 & 0.238 & 0.078 & 0.136 & 0.085 \\
\hline $\mathrm{k}_{0}$ (threshold) & 4.669 & 0.818 & 4.246 & 1.409 & 5.641 & 1.118 & 7.299 & 1.181 & & \\
\hline $\mathrm{k}_{1}$ (threshold) & 9.316 & 0.791 & 9.945 & 1.191 & 9.331 & 1.154 & 10.504 & 1.264 & 8.734 & 1.158 \\
\hline $\mathrm{k}_{2}$ (threshold) & 10.110 & 0.821 & 10.416 & 1.216 & 10.678 & 1.229 & 12.299 & 1.343 & 8.914 & 1.166 \\
\hline $\mathrm{k}_{3}$ (threshold) & 15.120 & 1.053 & 15.583 & 1.616 & 15.757 & 1.527 & 16.982 & 1.616 & 14.646 & 1.627 \\
\hline No. of sample (n) & \multicolumn{2}{|c|}{417} & \multicolumn{2}{|c|}{212} & \multicolumn{2}{|c|}{205} & \multicolumn{2}{|c|}{220} & \multicolumn{2}{|c|}{197} \\
\hline Log-LI zero & \multicolumn{2}{|c|}{955.772} & \multicolumn{2}{|c|}{474.340} & \multicolumn{2}{|c|}{460.574} & \multicolumn{2}{|c|}{516.771} & \multicolumn{2}{|c|}{375.674} \\
\hline Log-LI final & \multicolumn{2}{|c|}{623.661} & \multicolumn{2}{|c|}{299.444} & \multicolumn{2}{|c|}{300.077} & \multicolumn{2}{|c|}{338.755} & \multicolumn{2}{|c|}{232.086} \\
\hline Nagelkerke $\mathrm{R}^{2}$ & \multicolumn{2}{|c|}{0.611} & \multicolumn{2}{|c|}{0.629} & \multicolumn{2}{|c|}{0.607} & \multicolumn{2}{|c|}{0.613} & \multicolumn{2}{|c|}{0.607} \\
\hline
\end{tabular}

Note: $\beta=$ Estimate, S.E. $=$ Standard error, ns. $=$ Not significant.

The estimated coefficient and standard error for the eight factors of service quality are significant at the $90 \%$ confidence level. Factors with larger estimated coefficients are more critical in determining the overall passenger satisfaction with the LRT service quality. All values of the Nagelkerke $R^{2}$ range from 0.607 to 0.629 . Table 6 shows the results for all models.

The results for Model 1 (general model) showed that comfort, facilities, staff service, and provision of information have a significant impact on the overall satisfaction with the Kuala Lumpur LRT service. Staff service has the highest estimated coefficient $(\beta=0.180)$ and is the critical factor in Model 1. The model also showed that there is a significant difference the male and female passengers. Male passengers considered speediness, facilities, staff service, and provision of information as important factors influencing their satisfaction, while female passengers were concerned with comfort, facilities, and provision of information. Models 2 and 3 showed that facilities and provision of information had a considerable influence on the overall satisfaction of male and female passengers. Male passengers considered the speediness and staff service factors as critical, while female passengers are more concerned with comfort. Both age segments viewed comfort, staff service, and provision of information as important factors influencing their overall satisfaction (see Table 6). Passengers from the youngest age group considered signage as very important, although older LRT passengers think otherwise.

Table 6 shows that provision of information (all models), comfort (four models), and staff service (four models) wee the critical determiners of satisfaction in most segments. The facilities factor was important in determining satisfaction in the general, male, and female model. Safety and ticketing service were not critical factors in any of the segments. Signage was only significant in the model for the youngest passengers (aged between 18 and 30 years old). Similarly, speediness was a significant factor in one passenger segment (the male model). Except for provision of information, the factors that were significant in each segment are different (Table 5). 


\section{Discussion and Implications \\ 4.1. Theoretical Implications}

This study gathered specific and comprehensive information on passenger's perception of the LRT service quality through in-depth analysis by segmenting passenger's gender and age. The segmentation technique identified the critical factors influencing perceived service quality from different segments and determined the overall passenger satisfaction. This approach prevented data heterogeneity [31,42].

The measurement scales for factor analysis were eight factors that may influence passenger satisfaction, i.e., signage, comfort, speediness, safety, ticketing service, facilities, staff service, and provision of information. Shen et al. [58] used the same constructs to investigate passenger satisfaction with the urban rail transit in Suzhou, China. De Ona et al. [44] and Yanik et al. [61] considered similar factors, including comfort, safety, provision of information, staff service, and other factors, in their case studies in Italy and Turkey, respectively. Based on the previous research, the factors extracted from the factor analysis are those underlying the perceived service quality that could influence passenger satisfaction. In this research, signage, comfort, and facilities are the key factors explaining most of the variance.

This study found that the factors influencing the LRT service quality differed across passenger's gender and age. Each gender and age group has its own perception of the quality of service. This finding is supported by previous works in the transportation field $[31,45,70,71]$. According to Morton et al. [43], it is critical to understand the different attitudes towards public transportation service quality among the different sociodemographic segments in designing specific improvements to enhance passenger satisfaction with the provided service. This study discovered that male and female passengers have different perceptions of signage, comfort, speediness, ticketing service, facilities, and provision of information. There is also a significant difference between the different age groups regarding signage, comfort, speediness, facilities, and provision of information. This in-depth study provides useful insight into the improvement of the factors influencing specific service quality that can fulfill the mobility need of the specific passenger segments and enhance their satisfaction.

Passengers' gender and age influenced their perception of LRT service quality. The ordered logit model for all LRT passengers (general model) showed that comfort, facilities, staff service, and provision of information are the critical factors influencing overall passenger satisfaction with the provided service, which is similar to the results reported by Obsie et al. [45] and Wang et al. [72]. The different physical and biological traits, attitudes, and activities of both genders resulted in significant gender differences in perceived service quality and behavioral intention. According to Kwok et al. [73], the different ways male and female passengers make judgments, process, evaluate/retrieve information, and observe their environment contribute to the gender difference in the perception of LRT service quality.

The models in this study showed that speediness, facilities, staff service, and provision of information were the key factors in the overall satisfaction of male passengers with the LRT service. However, comfort, facilities, and provision of information were more critical in determining the overall satisfaction of female passengers. Female passengers did not consider the speediness and staff service as critical determiners of their satisfaction. This is in line with the findings of Allen et al. [74], who reported that the female public transportation users were more concerned with comfort and cleanliness. This finding is also congruent with those of Jiang and Zhang [75], who found that female passengers at Melbourne Airport gave a higher rating to comfort and convenience. In our study, male passengers were concerned with speediness, including punctual arrival and departure, acceptable service hours, and high-frequency service. Female passengers were more concerned with comfort during the journey, including adequate ventilation and comfortable temperature on the trains and at the stations, cleanliness at the station and on the train, and others. This may be related to the inherent nature of the trip. Male passengers depended on LRT to make compulsory trips such as commuting to work or appointments. Thus, 
speediness was the most influential factor of male passengers' overall satisfaction. Female passengers, on the other hand, tended to use the LRT for leisure trips such as going to shopping malls, and speediness is not an important factor since they are more concerned with comfort during the journey.

In terms of age group, signage, comfort, staff service, and provision of information were the determiners of the overall satisfaction of young passengers. Older passengers were not concerned with signage because they are more experienced in using the LRT service. This finding is supported by Bose and Pandit [70] and de Ona et al. [53], who highlighted that passenger's perception of the public transportation service quality is influenced by their experiences, habits, and behavioral intention.

Another interesting fact concerning satisfaction with the Kuala Lumpur LRT service was that safety and ticketing service did not influence overall satisfaction in all cases. This is in line with the findings of a case study in Shanghai, China, which reported that safety was not a critical factor in public transportation use [76]. This may be due to the passengers' confidence that the LRT trains and stations are safe and secure. The LRT service provider in Malaysia has installed proper lighting, provided a sufficient number of security guards at the stations, ensured proper design and layout of the stations, and installed a sufficient number of closed circuit televisions (CCTV) to monitor the conditions in the train and at the station to enhance the safety of LRT passengers. These measures can improve safety at the stations and on trains $[77,78]$. However, the findings on safety factors contradict previous works that reported the passengers' safety is a critical factor influencing the overall satisfaction with the provided service $[45,52,58]$. Female passengers often reported harassment, discrimination, and violence during their trips [79-81]. In addition, contrary to previous works [17,45], this study found that ticketing service did not influence passengers' satisfaction because the Kuala Lumpur LRT service provider provides sufficient ticketing facility including ticket vending machine and affordable ticketing options such as token (cash), Touch 'N Go (cashless), weekly pass (MyRapid TnG SMART7), and monthly pass (MyRapid TnG SMART30).

In summary, the critical factors that influenced overall passenger satisfaction in this study were access to information, comfort, staff service, and facilities. In three cases, facilities contribute to overall passenger satisfaction. However, staff service and comfort influenced overall passenger satisfaction in all four cases. Easy access to information was an important determinant of overall satisfaction in all cases or segments. This finding is consistent with previous research that found that the provision of information, comfort, and punctuality are the key factors influencing public transportation travel intentions $[27,61,76]$. Speediness and signage are critical factors to male passengers and younger passengers, respectively. Das et al. [52] and Irtema et al. [26] reported that speediness (in terms of frequency and punctuality) contributed to passenger satisfaction.

\subsection{Practical Implications}

The results of this study have several practical implications on the effort of LRT service providers to enhance passenger satisfaction and develop effective strategies for retaining the current passengers and attracting potential passengers. This finding is congruent with the implications reported by previous research that satisfied passengers are more likely to be loyal to the service provider $[17,18,82]$. As a consequence, the LRT service would be able to survive in a competitive transportation market in urban areas such as Kuala Lumpur.

There is a need to improve the factors investigated in this study-i.e., provision of information, comfort, staff service, and facilities - to ensure that a larger number of passengers are satisfied with the LRT service. It is not prudent to invest in improving safety and ticketing service since these factors are not critical in all segments. Provision of accurate, reliable, and up-to-date information at the stations and on the train can increase passenger satisfaction. According to Van Lierop et al. [18] and Machado-Leóna et al. [60], service providers and the relevant authorities must provide information on ticket fare, 
service interruptions, operating hours, train route, and schedule as this information is critical in enhancing passenger satisfaction with public transportation.

Staff service is one of the critical factors ensuring passenger satisfaction with the LRT service. The management team, drivers, and other employees of the LRT service providers contribute equally to ensuring passenger satisfaction. The service providers must ensure that their staff positively represents their business and company. The staff must be courteous and professional when dealing with passengers and provide precise, current, and reliable information. Professional-looking uniform can improve staff appearance [15]. Another critical factor that ensures passenger satisfaction with the LRT service is passenger comfort, which is influenced by factors such as temperature and cleanliness. According to Ibrahim et al. [15] and Geetika [83], the service provider should ensure passengers' comfort on the train and at the station as this could significantly enhance passenger satisfaction. Comfort includes thermal comfort and cleanliness on the train and at the station. One way to improve cleanliness at the LRT facilities is by providing more waste bins for the disposal of rubbish or waste and recycling bins to promote recycling of waste and to contribute to a greener environment [15]. Another policy that can improve the cleanliness of the LRT is prohibiting smoking, eating, and drinking on the train [63]. Passengers can contribute to ensuring that the public transportation service meets their expectation by abiding by the rules and regulations for cleanliness.

Service providers should provide sufficient facilities in the train and at the station. The provision of comfortable and adequate seating at the stations can improve passenger comfort while waiting for the train. According to Gao et al. [84], comfortable seating on the train could increase passenger satisfaction with public transport. Service providers should also install comfortable grab handles on the ceiling of LRT trains for standing passengers.

Service providers must not ignore the speediness and signage factors even though they are critical factors in ensuring passenger satisfaction in only one segment. Increasing the frequency of LRT service, especially during peak hours, will increase passenger satisfaction and LRT ridership. Trains must be in a good operating condition to ensure punctual arrival and departure. Also, installing clear and systematic signage can improve passenger satisfaction, especially among younger passengers.

\section{Conclusions and Suggestion for Future Study}

This study sought to determine the effect of gender and age on passengers' perception of the Kuala Lumpur LRT service quality based on eight factors: signage, comfort, speediness, safety, ticketing service, facilities, staff service, and provision of information. This study segmented passenger's age and gender in the in-depth analysis to obtain comprehensive information on passenger satisfaction in each segment and to avoid heterogeneity in perceptions. The results showed that the factors of LRT service quality influencing passenger satisfaction across gender and age varied significantly. In most segments, provision of information, comfort, staff service, and facilities were the critical determinants of passenger satisfaction. Safety and ticketing service had no impact on the overall passenger satisfaction in all segments. The findings of this study can help improve various aspects of the LRT service. Theoretically, the adoption of the heterogeneity approach provided fundamental knowledge of how gender and age shape passenger's perception of the service quality factors that influence their satisfaction with the LRT service. This study also contributed important information to the transportation literature, especially regarding the transportation scenario in the Asian region. In practical terms, this study identified the specific factors critical for determining the satisfaction of specific passenger segments. In summary, this study helped service providers, policymakers, and researchers to identify the effective and specific measures that could improve the LRT service quality by enhancing short-term passenger satisfaction and increasing LRT ridership. It also helps the service providers to maximize their profits and survive in the transportation market in the long-term.

Despite the theoretical and practical implications of this study, there are some limitations. This study can only be generalized to a limited extent because of the convenience 
sampling of LRT passengers from Klang Valley, Malaysia. Future studies should consider the perception of service quality of non-LRT passengers, such as the study on private transportation users by de Ona et al. [31]. Future studies should also be carried out in areas with a large population and target respondents who are not familiar with the Klang Valley area and LRT system to broaden the results. A comparative study of the Malaysian LRT system with those in other countries is beneficial because cross-cultural studies may give new insights about passengers' perception of LRT service quality. It is worth noting that the COVID-19 pandemic sweeping across the globe has changed the public transportation service and passenger's perception, as well as behavioral intention, towards public transportation service, including LRT. However, this study did not consider the effects of the COVID-19 pandemic since it focused only on the LRT passenger's perception of the normal LRT service. Future studies should explore passenger's perception of the LRT service during or post COVID-19 pandemic and compared their findings with that of this study since it may provide new information of how passengers' perception of the LRT service change with time and conditions.

Author Contributions: Conceptualization, A.N.H.I. and M.N.B.; methodology, A.N.H.I. and M.N.B.; software, A.N.H.I. and N.A.M.Y.; validation, A.N.H.I., N.A.M.Y. and Y.S.; formal analysis, A.N.H.I.; data curation, A.N.H.I. and M.N.B.; writing-original draft preparation, A.N.H.I. and N.A.M.Y.; writing-review and editing, A.N.H.I., M.N.B., M.R.M.Y. and Y.S.; supervision, M.N.B., N.I.M.Y. and A.I.; project administration, M.N.B.; funding acquisition, M.N.B. All authors have read and agreed to the published version of the manuscript.

Funding: This research was sponsored by Universiti Kebangsaan Malaysia (UKM) through Project GUP-2019-015 and the Ministry of Higher Learning Malaysia via Project FRGS/1/2017/TK08/ $\mathrm{UKM} / 01 / 1$.

Institutional Review Board Statement: Ethical review and approval were waived for this study, due to this study did not involve biological human experiment and patient data.

Informed Consent Statement: Informed consent was obtained from all subjects involved in the study.

Data Availability Statement: All relevant data are within the paper.

Acknowledgments: The first author would like to acknowledge Yayasan Canselor UKM for the doctoral scholarship under the Skim Zamalah Yayasan Canselor 2019. In addition, the authors would like to thank the anonymous reviewers for their helpful suggestions and comments.

Conflicts of Interest: The authors declare no conflict of interest.

Appendix A

\begin{tabular}{cc}
\hline Factor/Item & Abbrv. \\
\hline Signage & SG1 \\
Signage for the location of LRT station & SG2 \\
Provision of instructions at the station & SG3 \\
Signage for automatic gates at the station & SG4 \\
Clarity of the signage for direction & SG5 \\
Signal for train departure/arrival at the station & \\
Comfort & CF1 \\
Level of lighting at the station & CF2 \\
Cleanliness at the station & CF3 \\
Appropriate ventilation and temperature at the station & CF4 \\
Appropriate ventilation and temperature in the train & CF5 \\
\hline
\end{tabular}




\begin{tabular}{|c|c|}
\hline Factor/Item & Abbrv. \\
\hline \multicolumn{2}{|l|}{ Facilities } \\
\hline Suitable location for vending machines & FT1 \\
\hline Suitable location for train station waiting seats & FT2 \\
\hline Comfortable waiting seats & FT3 \\
\hline Comfortable armrest and ring setting in the train & FT4 \\
\hline Mobile signal strength at the stations & FT5 \\
\hline Mobile signal strength on the train & FT6 \\
\hline \multicolumn{2}{|l|}{ Speediness } \\
\hline Punctuality of train arrival & SN1 \\
\hline Acceptable train dwell time & SN2 \\
\hline Acceptable departure interval & SN3 \\
\hline Acceptable service time & SN4 \\
\hline \multicolumn{2}{|l|}{ Ticketing Service } \\
\hline Types of ticket offered & TS1 \\
\hline Number of ticket vending machine & TS2 \\
\hline Clarity of instruction on using the ticket vending machines & TS3 \\
\hline Convenience of money changing at the station & TS4 \\
\hline \multicolumn{2}{|l|}{ Staff Service } \\
\hline Staff appearance & SS1 \\
\hline Staff attitude & SS2 \\
\hline Staff efficiency in resolving passengers' problems & SS3 \\
\hline Response time of call centre during service hours & SS4 \\
\hline \multicolumn{2}{|l|}{ Safety } \\
\hline Safety at the station & ST1 \\
\hline Safety in the train & ST2 \\
\hline Safety during the travel & ST3 \\
\hline Behaviour of other passengers & ST4 \\
\hline Advance door closing announcement & ST5 \\
\hline \multicolumn{2}{|l|}{ Provision of Information } \\
\hline Publicity of the provided LRT service & PI1 \\
\hline Efficiency of service interruption announcement & PI2 \\
\hline \multirow{2}{*}{$\begin{array}{l}\text { Provision of information on the LRT service at the stations } \\
\text { Provision of information on the LRT services in the mass } \\
\text { media }\end{array}$} & PI3 \\
\hline & PI4 \\
\hline Overall Satisfaction with the LRT Service & OS \\
\hline
\end{tabular}

\section{References}

1. Borhan, M.N.; Ibrahim, A.N.H.; Syamsunur, D.; Rahmat, R.A. Why public bus is a less attractive mode of transport: A case study of Putrajaya, Malaysia. Period. Polytech. Transp. Eng. 2019, 47, 82-90. [CrossRef]

2. Kwan, S.C.; Sutan, R.; Hashim, J.H. Trip characteristics as the determinants of intention to shift to rail transport among private motor vehicle users in Kuala Lumpur, Malaysia. Sustain. Cities Soc. 2018, 36, 319-326. [CrossRef]

3. Chiu Chuen, O.; Karim, M.R.; Yusoff, S. Mode choice between private and public transport in Klang Valley, Malaysia. Sci. World J. 2014, 2014, 7-9. [CrossRef] [PubMed]

4. Ibrahim, A.N.H.; Borhan, M.N.; Rahmat, R.A.O.K. Understanding users' intention to use park-and-ride facilities in Malaysia: The role of trust as a novel construct in the theory of planned behaviour. Sustainability 2020, 12, 2484. [CrossRef]

5. Cools, M.; Fabbro, Y.; Bellemans, T. Free public transport: A socio-cognitive analysis. Transp. Res. Part A Policy Pr. 2016, 86, 96-107. [CrossRef]

6. Pucher, J.; Park, H.; Kim, M.; Song, J. Public transport reforms in Seoul: Innovations motivated by funding crisis. J. Public Transp. 2005, 41-62. [CrossRef]

7. Zefreh, M.M.; Hussain, B.; Sipos, T. In-depth analysis and model development of passenger satisfaction with public transportation. KSCE J. Civ. Eng. 2020, 24, 3064-3073. [CrossRef]

8. Mouwen, A. Drivers of customer satisfaction with public transport services. Transp. Res. Part A Policy Pr. 2015, 78, 1-20. [CrossRef]

9. Borhan, M.N.; Ibrahim, A.N.H.; Aziz, A.; Yazid, M.R.M. The relationship between the demographic, personal, and social factors of Malaysian motorcyclists and risk taking behavior at signalized intersections. Accid. Anal. Prev. 2018, 121, 94-100. [CrossRef]

10. Soehodho, S. Public transportation development and traffic accident prevention in Indonesia. IATSS Res. 2017, 40, 76-80. [CrossRef]

11. Satiennam, T.; Jaensirisak, S.; Satiennam, W.; Detdamrong, S. Potential for modal shift by passenger car and motorcycle users towards bus rapid transit (BRT) in an Asian developing city. IATSS Res. 2016, 39, 121-129. [CrossRef]

12. Kwan, S.C.; Tainio, M.; Woodcock, J.; Sutan, R.; Hashim, J.H. The carbon savings and health co-benefits from the introduction of mass rapid transit system in Greater Kuala Lumpur, Malaysia. J. Transp. Health 2017, 6, 187-200. [CrossRef] 
13. Nasrudin, N.; Mohd Noor, H.; Abdullah, Y.A. Public awareness towards sustainable transportation in Shah Alam, Malaysia. Asian J. Behav. Stud. 2018, 3, 137-146. [CrossRef]

14. Borhan, M.N.; Mohd Akhir, N.; Ismail, A.; Rahmat, R.A.A. Pemodelan hubungan antara kualiti perkhidmatan, kesan alam sekitar, sikap dan keinginan untuk menggunakan park-and-ride. J. Kejuruter. 2015, 27, 63-70. [CrossRef]

15. Ibrahim, A.N.H.; Borhan, M.N.; Yusoff, N.I.; Ismail, A. Rail-based public transport service quality and user satisfaction-A literature review. Promet-Traffic Transp. 2020, 32, 423-435. [CrossRef]

16. Mohamad Zulkifli, S.N.A.; Kadar Hamsa, A.A.; Noor, N.M.; Ibrahim, M. Evaluation of land use density, diversity and ridership of rail based public transportation system. Transp. Res. Procedia 2017, 25, 5266-5281. [CrossRef]

17. Ibrahim, A.N.H.; Borhan, M.N.; Zakaria, N.A.; Zainal, S.K. Effectiveness of commuter rail service toward passenger's satisfaction: A case study from Kuala Lumpur, Malaysia. Int. J. Eng. Technol. 2019, 8, 50-55. [CrossRef]

18. Van Lierop, D.; Badami, M.G.; El-Geneidy, A.M. What influences satisfaction and loyalty in public transport? A review of the literature. Transp. Rev. 2018, 38, 52-72. [CrossRef]

19. Masirin, M.I.M.; Salin, A.M.; Zainorabidin, A.; Martin, D.; Samsuddin, N. Review on Malaysian rail transit operation and management system: Issues and solution in integration. IOP Conf. Ser. Mater. Sci. Eng. 2017, 226, 1-7. [CrossRef]

20. Jomnonkwao, S.; Champahom, T.; Ratanavaraha, V. Methodologies for determining the service quality of the intercity rail service based on users' perceptions and expectations in Thailand. Sustainability 2020, 12, 4259. [CrossRef]

21. Díez-Mesa, F.; de Oña, R.; de Oña, J. Bayesian networks and structural equation modelling to develop service quality models: Metro of Seville case study. Transp. Res. Part A Policy Pr. 2018, 118, 1-13. [CrossRef]

22. Chou, J.S.; Kim, C. A structural equation analysis of the QSL relationship with passenger riding experience on high speed rail: An empirical study of Taiwan and Korea. Expert Syst. Appl. 2009, 36, 6945-6955. [CrossRef]

23. Kuo, C.-W.; Tang, M.-L. Relationship among service quality, corporate image, customer satisfaction and behaviroal intention for the elderly in high speed rail service. J. Adv. Transp. 2013, 47, 512-525. [CrossRef]

24. Ibrahim, A.N.H.; Borhan, M.N. The interrelationship between perceived quality, Perceived value and user satisfaction towards behavioral intention in public transportation: A review of the evidence. Int. J. Adv. Sci. Eng. Inf. Technol. 2020, 10, 2048-2056. [CrossRef]

25. Morfoulaki, M.; Tyrinopoulos, Y.; Aifadopoulou, G. Estimation of satisfied customers in public transport systems: A new methodological approach. J. Transp. Res. Forum 2007, 46, 63-72. [CrossRef]

26. Irtema, H.I.M.; Ismail, A.; Borhan, M.N.; Das, A.M.; Alshetwi, A.B.Z. Case study of the behavioural intentions of public transportation passengers in Kuala Lumpur. Case Stud. Transp. Policy 2018, 6, 462-474. [CrossRef]

27. Yilmaz, V.; Ari, E. The effects of service quality, image, and customer satisfaction on customer complaints and loyalty in high-speed rail service in Turkey: A proposal of the structural equation model. Transp. A Transp. Sci. 2017, 13, 67-90. [CrossRef]

28. Zhang, C.; Liu, Y.; Lu, W.; Xiao, G. Evaluating passenger satisfaction index based on PLS-SEM model: Evidence from Chinese public transport service. Transp. Res. Part A Policy Pr. 2019, 120, 149-164. [CrossRef]

29. Yuan, Y.; Yang, M.; Wu, J.; Rasouli, S.; Lei, D. Assessing bus transit service from the perspective of elderly passengers in Harbin, China. Int. J. Sustain. Transp. 2019, 13, 761-776. [CrossRef]

30. Lai, W.T.; Chen, C.F. Behavioral intentions of public transit passengers-the roles of service quality, perceived value, satisfaction and involvement. Transp. Policy 2011, 18, 318-325. [CrossRef]

31. De Oña, J.; Estévez, E.; de Oña, R. Perception of public transport quality of service among regular private vehicle users in Madrid, Spain. Transp. Res. Rec. 2020, 2674, 213-224. [CrossRef]

32. Patterson, Z.; Darbani, J.M.; Rezaei, A.; Zacharias, J.; Yazdizadeh, A. Comparing text-only and virtual reality discrete choice experiments of neighbourhood choice. Landsc. Urban. Plan. 2017, 157, 63-74. [CrossRef]

33. Farooq, B.; Cherchi, E.; Sobhani, A. Virtual immersive reality for stated preference travel behavior experiments: A case study of autonomous vehicles on urban roads. Transp. Res. Rec. 2018, 2672, 35-45. [CrossRef]

34. Kredel, R.; Vater, C.; Klostermann, A.; Hossner, E.J. Eye-tracking technology and the dynamics of natural gaze behavior in sports: A systematic review of 40 years of research. Front. Psychol. 2017, 8, 1845. [CrossRef]

35. Borowsky, A.; Shinar, D.; Oron-Gilad, T. Age, skill, and hazard perception in driving. Accid. Anal. Prev. 2010, 42, 1240-1249. [CrossRef] [PubMed]

36. Vetturi, D.; Tiboni, M.; Maternini, G.; Bonera, M. Use of eye tracking device to evaluate the driver's behaviour and the infrastructures quality in relation to road safety. Transp. Res. Procedia 2020, 45, 587-595. [CrossRef]

37. Barrado-Timón, D.A.; Hidalgo-Giralt, C. The historic city, its transmission and perception via augmented reality and virtual reality and the use of the past as a resource for the present: A new era for urban cultural heritage and tourism? Sustainability 2019, 11, 2835. [CrossRef]

38. Diemer, J.; Alpers, G.W.; Peperkorn, H.M.; Shiban, Y.; Mühlberger, A. The impact of perception and presence on emotional reactions: A review of research in virtual reality. Front. Psychol. 2015, 6, 26. [CrossRef]

39. Lieze, M.; Jelle, V.C.; Benedicte, D.; de Nico, V.W.; Mario, M.; van Dyck, D. Using virtual reality to investigate physical environmental factors related to cycling in older adults: A comparison between two methodologies. J. Transp. Health 2020, 19. [CrossRef] 
40. Sobhani, A.; Farooq, B.; Zhong, Z. Distracted pedestrians crossing behaviour: Application of immersive head mounted virtual reality. In Proceedings of the 2017 IEEE 20th International Conference on Intelligent Transportation Systems (ITSC), Yokohama, Japan, 16-19 October 2017; pp. 1-6.

41. Simpson, G.; Johnston, L.; Richardson, M. An investigation of road crossing in a virtual environment. Accid. Anal. Prev. 2003, 35, 787-796. [CrossRef]

42. De Oña, J.; De Oña, R. Quality of service in public transport based on customer satisfaction surveys: A review and assessment of methodological approaches. Transp. Sci. 2015, 49, 605-622. [CrossRef]

43. Morton, C.; Caulfield, B.; Anable, J. Customer perceptions of quality of service in public transport: Evidence for bus transit in Scotland. Case Stud. Transp. Policy 2016, 4, 199-207. [CrossRef]

44. De Oña, J.; de Oña, R.; Eboli, L.; Mazzulla, G. Heterogeneity in perceptions of service quality among groups of railway passengers. Int. J. Sustain. Transp. 2015, 9, 612-626. [CrossRef]

45. Obsie, A.; Woldeamanuel, M.; Woldetensae, B. Service quality of addis ababa light rail transit: Passengers' views and perspectives. Urban. Rail Transit. 2020, 6, 231-243. [CrossRef]

46. Bellizzi, M.G.; Eboli, L.; Forciniti, C.; Mazzulla, G. Air transport passengers' satisfaction: An ordered logit model. Transp. Res. Procedia 2018, 33, 147-154. [CrossRef]

47. Beirão, G.; Cabral, J.S. Market segmentation analysis using attitudes toward transportation exploring the differences between men and women. Transp. Res. Rec. J. Transp. Res. Board 2008, 2067, 56-64. [CrossRef]

48. Fellesson, M.; Friman, M. Perceived satisfaction with public transport service in nine european cities. J. Transp. Res. Forum 2012, 47, 93-103. [CrossRef]

49. Jensen, M. Passion and heart in transport-A sociological analysis on transport behaviour. Transp. Policy 1999, 6, 19-33. [CrossRef]

50. Şimşekoğlu, Ö.; Nordfjærn, T.; Rundmo, T. The role of attitudes, transport priorities, and car use habit for travel mode use and intentions to use public transportation in an urban Norwegian public. Transp. Policy 2015, 45, 113-120. [CrossRef]

51. Githui, J.N.; Okamura, T.; Nakamura, F. The structure of users' satisfaction on urban public transport service in developing country: The case of Nairobi. J. East. Asia Soc. Transp. Stud. 2010, 8, 1288-1300. [CrossRef]

52. Das, A.M.; Ladin, M.A.; Ismail, A.; Rahmat, R.O.K. Consumers satisfaction of public transport monorail user in Kuala Lumpur. J. Eng. Sci. Technol. 2013, 8, 272-283.

53. De Oña, J.; De Oña, R.; Eboli, L.; Mazzulla, G. Perceived service quality in bus transit service: A structural equation approach. Transp. Policy 2013, 29, 219-226. [CrossRef]

54. De Oña, R.; Eboli, L.; Mazzulla, G. Key factors affecting rail service quality in the Northern Italy: A decision tree approach. Transport 2014, 29, 75-83. [CrossRef]

55. Grujičić, D.; Ivanović, I.; Jović, J.; Đorić, V. Customer perception of service quality in public transport. Transport 2014, 29, 285-295. [CrossRef]

56. Susilo, Y.O.; Cats, O. Exploring key determinants of travel satisfaction for multi-modal trips by different traveler groups. Transp. Res. Part A Policy Pr. 2014, 67, 366-380. [CrossRef]

57. Nwachukwu, A.A. Assessment of passenger satisfaction with intra-city public bus transport services in Abuja, Nigeria. J. Public Transp. 2014, 17, 99-119. [CrossRef]

58. Shen, W.; Xiao, W.; Wang, X. Passenger satisfaction evaluation model for Urban rail transit: A structural equation modeling based on partial least squares. Transp. Policy 2016, 46, 20-31. [CrossRef]

59. Eboli, L.; Fu, Y.; Mazzulla, G. Multilevel comprehensive evaluation of the railway service quality. Procedia Eng. 2016, 137, 21-30. [CrossRef]

60. Machado-Leóna, J.L.; de Oñaa, R.; Baounib, T.; de Oñaa, J. Railway transit services in algiers: Priority improvement actions based on users perceptions. Transp. Policy 2017, 53, 175-185. [CrossRef]

61. Yanik, S.; Aktas, E.; Topcu, Y.I. Traveler satisfaction in rapid rail systems: The case of Istanbul metro. Int. J. Sustain. Transp. 2017, 11, 642-658. [CrossRef]

62. United Nations. World Urbanization Prospects: The 2018 Revision; United Nations: New York, NY, USA, 2019 ; Volume 12.

63. Borhan, M.N.; Ibrahim, A.N.H.; Miskeen, M.A.A. Extending the theory of planned behaviour to predict the intention to take the new high-speed rail for intercity travel in Libya: Assessment of the influence of novelty seeking, trust and external influence. Transp. Res. Part A Policy Pr. 2019, 130, 373-384. [CrossRef]

64. Borhan, M.N.; Ibrahim, A.N.H.; Miskeen, M.A.A.; Rahmat, R.A.O.K.; Alhodairi, A.M. Predicting car drivers' intention to use low cost airlines for intercity travel in Libya. J. Air Transp. Manag. 2017, 65, 88-98. [CrossRef]

65. Maskey, R.; Fei, J.; Nguyen, H.O. Use of exploratory factor analysis in maritime research. Asian J. Shipp. Logist. 2018, 34, 91-111. [CrossRef]

66. Kaiser, H.F. The Application of Electronic Computers to Factor Analysis. Educ. Psychol. Meas. 1960, 20, 141-151. [CrossRef]

67. Ibrahim, A.N.H.; Borhan, M.N.; Mhd Yunin, N.A. Getting young drivers to buckle up: Exploring the factors influencing seat belt use by young drivers in Malaysia. Sustainability 2021, 13, 162. [CrossRef]

68. Uca, S.; Altintas, V.; Tuzunkan, D.; Toanoglou, M. A study on the effects of demographic factors on hotel selection process. Int. J. Tour. Sci. 2017, 17, 231-246. [CrossRef]

69. Hair, J.F.; Black, W.C.; Babin, B.J.; Anderson, R.E. Multivariate Data Analysis, 7th ed.; Pearson: London, UK, 2014. 
70. Bose, T.; Pandit, D. Heterogeneity in perception of service quality attributes of bus transit across various user categories: A case of Kolkata. Transp. Res. Procedia 2020, 48, 2784-2799. [CrossRef]

71. Bellizzi, M.G.; dell'Olio, L.; Eboli, L.; Mazzulla, G. Heterogeneity in desired bus service quality from users' and potential users' perspective. Transp. Res. Part A Policy Pr. 2020, 132, 365-377. [CrossRef]

72. Wang, Y.; Cao, M.; Liu, Y.; Ye, R.; Gao, X.; Ma, L. Public transport equity in Shenyang: Using structural equation modelling. Res. Transp. Bus. Manag. 2020. [CrossRef]

73. Kwok, S.Y.; Jusoh, A.; Khalifah, Z. The influence of service quality on satisfaction: Does gender really matter? Intang. Cap. 2016, 12, 444-461. [CrossRef]

74. Allen, J.; Eboli, L.; Mazzulla, G.; de Ortúzar, J.D. Effect of critical incidents on public transport satisfaction and loyalty: An ordinal probit SEM-MIMIC approach. Transportation 2020, 47, 827-863. [CrossRef]

75. Jiang, H.; Zhang, Y. An assessment of passenger experience at Melbourne Airport. J. Air Transp. Manag. 2016, 54, 88-92. [CrossRef]

76. Li, L.; Cao, M.; Bai, Y.; Song, Z. Analysis of public transportation competitiveness based on potential passenger travel intentions: Case study in Shanghai, China. Transp. Res. Rec. 2019, 2673, 823-832. [CrossRef]

77. Azizan, F.A.; Mohamed, N.F.; Rahman, Z.A.; Aziz, N.A. Statistical evaluation of commuters' perception on safety and crime rate: A study among women passengers of KTM Komuter in Kuala Lumpur. AIP Conf. Proc. 2016, 1774. [CrossRef]

78. Abdul Hamid, N.; Tan, P.-L.; Mohamad Zali, M.F.; Rahamat, N.U.; Abd Aziz, N. Safety and security needs of commuter rail services-travellers' perceptions. J. East. Asia Soc. Transp. Stud. 2015, 11, 1495-1506. [CrossRef]

79. Dunckel Graglia, A. Finding mobility: Women negotiating fear and violence in Mexico City's public transit system. Gend. Place Cult. 2016, 23, 624-640. [CrossRef]

80. Chowdhury, S.; van Wee, B. Examining women's perception of safety during waiting times at public transport terminals. Transp. Policy 2020, 94, 102-108. [CrossRef]

81. Quinones, L.M. Sexual harassment in public transport in Bogotá. Transp. Res. Part A Policy Pr. 2020, 139, 54-69. [CrossRef]

82. Joewono, T.B.; Kubota, H. Paratransit service in Indonesia: User satisfaction and future choice. Transp. Plan. Technol. 2008, 31, 325-345. [CrossRef]

83. Geetika, S.N. Determinants of Customer Satisfaction on Service Quality: A Study of Railway Platforms in India. J. Public Transp. 2010, 13, 97-113. [CrossRef]

84. Gao, L.; Yu, Y.; Liang, W. Public Transit Customer Satisfaction Dimensions Discovery from Online Reviews. Urban Rail Transit. 2016, 2, 146-152. [CrossRef] 